\title{
Blockchain technology in tax law theory and tax administration
}

\author{
Olga I. Lyutova ${ }^{1} \bowtie$, Irina D. Fialkovskaya ${ }^{2}$ \\ ${ }^{1}$ National Research University Higher School of Economics (NRU HSE), \\ Moscow, Russian Federation \\ ${ }^{2}$ National Research Nizhny Novgorod State University named after N.I. Lobachevsky, \\ Nizhny Novgorod, Russian Federation \\ \olyutova@hse.ru
}

\begin{abstract}
The article is devoted to the problems of improving the tax legislation of Russia at the stage of active implementation of blockchain technology, which is characterized by contradictory trends in the legal regulation of digital technologies. The relevance of the study of application of blockchain in tax relations is due to the need to assess the tax consequences of transactions using digital financial assets, as well as emergence of new directions for improving tax control based on blockchain technology. The purpose of the study is to analyze the provisions of Russian and foreign tax legislation, as well as doctrinal sources on improving legal regulation of tax relations in regard to blockchain technology. The study shows efficacy of the blockchain analysis for the purposes of tax and legal regulation carried out by developing concepts related to applying such technological solution as a tool in conducting cryptocurrency transactions. The theoretical significance of the study lies in the author's definition of the concept of blockchain technology for tax purposes, as well as in proving the value of legal regulation of tax relations applying blockchain. The practical implication is connected with voicing the need to develop legal regulation of applying blockchain technology when creating a system of transactional (automatic) taxation and levying the so-called "smart taxes" while fulfilling tax obligations in the context of introducing a goods traceability mechanism. This will also contribute to minimizing tax reporting. The research methodology are general and private scientific methods of knowledge: formal-legal, analysis, comparative-legal, and forecasting and modeling. The last two are often applied in tax law in light of digitalization and globalization.
\end{abstract}

Key words: blockchain technology, a distributed registry, tax duties, cryptocurrency, smart contract, tax administration, traceability, professional income tax, self-employed, transactional taxation

Conflicts of interest. The authors declared no conflicts of interest.

The participation of the authors: inseparable co-authorship.

Funding information. The work was supported by the RFBR grant № 18-29-16107 mk on "Research and justification of the choice of a tax model in the era of digital transformation".

Article received 10th February 2021

Article accepted 15th July 2021

(C) Lyutova O.I., Fialkovskaya I.D., 2021

(c) (i) This work is licensed under a Creative Commons Attribution 4.0 International License https://creativecommons.org/licenses/by/4.0 


\title{
For citation:
}

Lyutova, O.I., Fialkovskaya, I.D. (2021) Blockchain technology in tax law theory and tax administration. RUDN Journal of Law. 25 (3), 693-710. DOI: 10.22363/2313-2337-2021-253-693-710

DOI: $10.22363 / 2313-2337-2021-25-3-693-710$

Научная статья

\section{Применение технологии блокчейн в налоговом администрировании}

\author{
О.И. Лютова ${ }^{1} \mathbb{D} \bowtie$, И.Д. Фиалковская ${ }^{2}$ \\ ${ }^{1}$ Национальный исследовательский университет «Высшая школа экономики», \\ 2. Москва, Российская Федерачия \\ ${ }^{2}$ Национальный исследовательский Нижегородский государственный университет \\ им. Н.И. Лобачевского, \\ г. Нижний Новгород, Российская Федераиия \\ $\bowtie$ olyutova@hse.ru
}

\begin{abstract}
Аннотация. Освящены проблемы совершенствования налогового законодательства России на этапе активного внедрения блокчейн-технологии, который характеризуется противоречивостью тенденций правового регулирования цифровых технологий. Актуальность исследования вопросов применения блокчейна в налоговых отношениях обуславливается необходимостью оценки налоговых последствий сделок, совершаемых с использованием цифровых финансовых активов, основанных на технологии блокчейн, а также появлением новых направлений совершенствования налогового контроля с применением блокчейн-технологии. Цель исследования провести анализ положений российского и зарубежного налогового законодательства, а также доктринальных источников по вопросу формирования направлений совершенствования правового регулирования налоговых отношений, реализуемых при условии использования блокчейнтехнологии. Проведенное исследование показывает опосредованность анализа блокчейна для целей налогово-правового регулирования, осуществляемого путем выработки концепций использования такого технологического решения в качестве инструмента при осуществлении криптовалютных операций. Теоретическая значимость исследования заключается в авторском определении понятия блокчейн-технологии для целей налогообложения, а также в доказательстве факта ценности правового регулирования налоговых отношений с применением блокчейна. Практическая значимость выражается в формулировании вывода о необходимости развития правового регулирования использования технологии блокчейн при создании системы транзакционного (автоматического) налогообложения и взимании так называемых «умных налогов», при исполнении налоговых обязанностей в условиях внедрения механизма прослеживаемости товаров, а также для минимизации налоговой отчетности. В качестве методов исследования избраны общенаучные и частнонаучные методы познания: формально-юридический, анализа, сравнительно-правовой, а также методы прогнозирования и моделирования, применяемость которых в налоговом праве возрастает под влиянием факторов цифровизации и глобализации.
\end{abstract}

Ключевые слова: блокчейн-технология, распределенный реестр, налоговые обязанности, криптовалюта, смарт-контракт, налоговое администрирование, прослеживаемость, налог на профессиональный доход, самозанятые, транзакционное налогообложение 
Конфликт интересов. Авторы заявляют об отсутствии конфликта интересов.

Информация о вкладе авторов: нераздельное соавторство.

Информация о финансировании. Работа выполнена при поддержке гранта РФФИ № 18-29-16107 мк на тему: «Исследование и обоснование выбора модели налогообложения в эпоху цифровой трансформации».

Дата поступления в редакиию: 10 февраля 2021 г.

Дата принятия к печати: 15 июня 2021 г.

\section{Для цитирования:}

Лютова О.И., Фиалковская И.Д. Применение технологии блокчейн в налоговом администрировании // RUDN Journal of Law. 2021. Т. 25. № 3. С. 693-710. DOI: $10.22363 / 2313-2337-2021-25-3-693-710$

\section{Introduction}

Digitalization is one of the most ambitious challenges for all branches of Russian law. In the field of taxation and fees, the process of introducing new digital technologies is manifested as substantial since there is no possibility at present to imagine implementation of tax administration as well as development of the tax law theory without taking into account the impact of the factor of technological development on real tax relations.

At the same time, it is generally recognized that the most discussed digital technology in legal science is blockchain. According to the fair remark of E.V. Talapina (Talapina, 2019:77-82), the whole world, to one degree or another, is trying to understand where blockchain can be used, what risks it avoids, and what, on the contrary, it creates.

It should be noted that blockchain technology as such is not a new phenomenon, and its practical application and theoretical studies have traditionally been associated with the fact that it is a necessary technological condition for cryptocurrencies, as well as a necessary technological element in the process of smart contracts functioning.

This means that the task of developing both general legal and sectoral (first of all in the field of tax law) approaches to the issue of legalization in general, as well as to the normative regulation of the scope, forms and methods of using blockchain technology is recognized as one of the primary tasks of the state. For tax law, it is relevant in terms of applying blockchain technology to reduce the costs associated with document flow. In 2020, based on the blockchain technology, a digital platform of the Federal Tax Service of Russia was set up ${ }^{1}$; it provides information exchange between

\footnotetext{
${ }^{1}$ Decree of the Government of the Russian Federation dated 02.04.2020 No. 422 "On approval of the Rules for the provision of subsidies from the federal budget to Russian credit institutions for reimbursement of lost income on loans issued in 2020 to small and medium-sized businesses for urgent needs to support and maintain employment" // Collection of legislation of the Russian Federation. 2020. No. 15 (part IV). Art. 2279; Resolution of the Government of the Russian Federation dated May 16, 2020 No. 696 "On Approval of the Rules for Granting Subsidies from the Federal Budget to Russian Credit Institutions for Reimbursement of Lost
} 
taxpayers, banks (VTB and Sberbank were the first to connect, and later other banks joined the project), extra-budgetary funds and tax authorities to ensure concessional lending to small and medium-sized businesses in the context of the new coronavirus infection (COVID-19) ${ }^{2}$. Besides it is planned to expand introduction of blockchain technologies into tax relations to completely abandon tax reporting.

In our opinion, these facts and processes add to the relevance of blockchain technology from the point of view of legal consequences analysis of its expansion in the field of taxation. Such analysis should be based on theoretical studies related, first of all, to the assessment of the blockchain technology in terms of existence/nonexistence of legal content. Then it will be clear whether there is the need to develop appropriate legal regulation and/or transform the existing tax legislation of the Russian Federation to create the conditions for the progressive development of digital economy allowing to actively apply the blockchain technology in tax administration, as well as establish and execute tax obligations.

To date, a significant number of studies have been accumulated and various normative acts have been adopted. Some of them raised dispute concerning the technolegal aspects of legal regulation of tax relations. Presumably, the time has come to summarize such discussions and assess the prospects for the development of the tax legislation of the Russian Federation in the context of introduction of blockchain technology into relations between taxpayers and tax authorities.

\section{Blockchain as a category of tax law: state and prospects of legal regulation}

The definition of the concept of blockchain for the purposes of tax and legal regulation determines studying its meaning in a general legal context. The term "blockchain", stemming from technological sphere, is ambiguous. The palette of opinions on the legal nature of blockchain due to the absence of its legal definition is widely represented both in domestic (Tabernakulov \& Koifman, 2019:3-28) and foreign literature (Abramov et al., 2019; Antonopoulos, 2014; Tapscott D. \& Tapscott A, 2016; Xu \& Huang, 2020:17434-17441).

The definition of a blockchain is most often formulated by listing its necessary and sufficient features. In our opinion, a uniform understanding of blockchain is fundamentally important since it may serve as a theoretical basis for the formation of legal regulation in the field of application of this technology in practice. Currently there are no such concepts as "blockchain" and "blockchain technology" either in Russian legislation or in legal science as there is no legal regulation of financial (including banking, payment and tax) system functioning with respect to such technology.

\footnotetext{
Incomes on Loans Issued in 2020 to Legal Entities and Individual Entrepreneurs for the Resumption of Activities" // Collected Legislation of the Russian Federation. 2020. No. 21. Art. 3277.

${ }^{2}$ See: Information of the Federal Tax Service of Russia dated 04/23/2020 "Daniil Egorov presented a service for confirming concessional loans to businesses at a video meeting with the President of Russia" // The document was not published. Access mode of the SPS "ConsultantPlus".
} 
The issue of the need for legislative definition of the concept of blockchain seems rather controversial and requires further scientific discussions since today blockchain is a projection solution, the architecture of which is especially promising in the financial sector, primarily because of its potential for cost reduction.

Currently, most researchers adhere to the opinion that there is no need for legal regulation of the concept of blockchain technology both in a general manner and specifics of industry regulation. For example, K.V. Nam (Nam, 2019:24-27) argues that it would be better if blockchain is not normatively defined since, in his opinion, the legal definition of technical solutions cannot always bring certainty to legal regulation, and vice versa. E.Yu. Barakina is of the opinion that it is not technologies that should be subject to regulation, but the activities carried out with their use (Barakina, 2018:53-58).

Besides, there is an opinion that from a legal point of view it is the digital asset, subject for exchange in the blockchain, that matters, and the blockchain itself only sets certain technical properties that lawyers need to distinguish between blockchain and other technologies (Rozhkova, 2018:336). In turn, we believe that if the scientific community and the legislator come to the conclusion that there is need for legal regulation of the blockchain or its individual properties (functions), then it is worth considering the issue of developing an appropriate concept to identify the tax consequences of the activities of entities using blockchain technology.

In tax law, the blockchain category also did not develop as a distinctive phenomenon. For the purposes of tax and legal regulation, the main discussions were focused on the problem of establishing the tax consequences of activities using cryptocurrencies, indicating that blockchain is the technological basis for their functioning.

An example of application of the concept of blockchain in modern tax relations is the legal regulation of digital financial assets and digital currency recognised with the adoption and entry into force of the Federal Law No. 259-FZ of July 31, 2020 On Digital Financial Assets, Digital Currency and Amendments to Certain Legislative Acts of the Russian Federation (hereinafter referred to as the Federal Law On DFA); as a result, the concept of a digital financial asset has been shaped. Its release, accounting and circulation is possible only by making (changing) entries in the information system based on a distributed register. It is important to note that the Federal Law "On DFA" did not include the rules on the peculiarities of taxation of digital currencies despite their obvious need, which has been repeatedly emphasized in the literature on tax law (Zhuravlev, Brisov, Yankovsky \& Levashenko, 2020:32-35). For this reason, the Draft Law No. 1065710-7 "On Amendments to Parts One and Two of the Tax Code of the Russian Federation (in terms of taxation of cryptocurrencies)"3 supplements paragraph 2 of Article 38 of the Tax Code of the Russian Federation with the provision recognising digital money as property subject to tax purposes. Some

\footnotetext{
${ }^{3}$ The system for ensuring the legislative activity of the State Automated System "Lawmaking". Available at: https://sozd.duma.gov.ru/bill/1065710-7 / [Accessed of February 5, 2020].
} 
additions to and amendments of certain norms of the second part of the Tax Code were also introduced.

Strictly speaking, the novelties of tax legislation warranted by the emergence of a digital financial asset do not solve the most important issues related to taxation of taxpayers" activities connected with blockchain technology. It is assumed that the association of a digital financial asset for tax purposes with other property is temporary and entails a number of problems of tax law enforcement.

Another reason to recognise the need to apply blockchain technology in tax law is a significant amount of information carried out between participants in tax relations. As you know, the bulk of such information exists in electronic form and is processed by numerous digital services of the Russian Federal Tax Service (for example, ASK "VAT" and AIS "Taxpayer"). At the same time, part of such information, in terms of its structure and content, is electronic registers (in particular, the register type has the Unified State Register of Legal Entities and the Unified State Register of Sole/Individual Entrepreneurs), which are of a public nature and are constantly updated. However, they are not engaged in blockchain operations due to the lack of absolute involvement of private subjects of tax relations.

This gives grounds to define blockchain technology as a theoretical basis for further formation of tax and legal regulation. So, we believe that for the purposes of legal regulation of taxation blockchain technology can be described as a database of assets implemented by a digital (technological) platform that ensures effective interaction between participants in tax relations.

Thus, tax legislation has not yet undergone revolutionary changes associated with recognition of digital financial assets; the need to develop new approaches to both transformation of traditional categories of tax law and development of tax and legal regulation of digital entities is evident. At the same time, the need for active implementation of blockchain technology in tax relations urges the development of appropriate legal regulation to use such technology in taxation.

\section{Blockchain technology in tax administration: risks and prospects of application}

Blockchain technology is one of the digital tools traditionally considered by tax researchers as a promising tool for improving tax administration and automating business processes (Tikhonova, 2020:6).

This determines the study of blockchain technology as the basis of tax procedural law of the digital period and assessment of possibilities for its application in the tax process. At the same time, we consider it important to explain the meaning of the concept of tax administration used in this study. The term is used in the context of assessing the development of tax legislation through the active use of blockchain technology in the activities of tax authorities.

In the absence of a legal definition of the concept tax administration in the science of tax law, it was conventionally accepted to understand it as the activity of tax 
authorities in exercising tax control over statutory compliance by organizations and individuals. When assessing the directions for improving tax administration, the exclusively imperative manner of the term is often criticized. For example, I.V. Mamonova notes the value of transparent combination of interests of participants in tax relations in defining the concept of tax administration and emphasizes the correctness of its understanding in a broader sense, adequate to modern realities. She suggests interpreting it as interaction of all participants in tax legal relations ensuring the parity of their interests and effective functioning of tax mechanism (Mamonova, 2018:37 - 41). A.V. Demin points out that in order to achieve the goal of forming constructive interaction between taxpayers and tax authorities, tax administration should be based on the principles of mutual trust, understanding, transparency and cooperation (Demin, 2017).

We think that in the context of active introduction of digital technologies, including blockchain technology, the core feature is transition of tax administration from the predominantly imperious nature of tax relations to constructive cooperation between private and public subjects of tax law. Thus, for the purposes of this study, tax administration will be understood as a system of organizational measures carried out by tax and other state bodies to form a service tax environment that ensures not only satisfaction of the budgetary interests of public law entities associated with the full and timely budget replenishment but also the mechanisms of partnership with taxpayers to stimulate their voluntary fulfilment of tax obligations.

It should be noted that significant attention is paid to the employment of blockchain technology by various government bodies of the Russian Federation. The tax authorities are known to be the leader among other state bodies in the development of new technologies (Migacheva, 2018:21-25).

For example, the possibilities of distributed ledger technology applied by tax authorities in their interaction with taxpayers and other private entities are described by A.V. Varnavsky in the monograph "Blockchain in the service of the state": they involve automation of VAT payment, personal income tax and insurance premiums (Varnavsky, Buryakova \& Sebechenko: 2020:35-46).

In particular, the author notes that the use of blockchain technology in administering taxes will lead to a total rejection of tax declarations due to formation of decentralized information database able to track the chains of taxable transactions in real time and ensure the automatic execution of tax obligations.

This approach seems to be quite reasonable, since, as V.E. Rodygina (Tsindeliani, 2019:243) asserts, one of the main challenges in the field of tax administration in the last decade have been various tax evasion schemes and illegal VAT refunds from the budget. In this regard, it seems quite logical to improve legal regulation of tax administration with new technological achievements. It is most relevant for indirect taxation where the use of blockchain will allow to algorithmize formation of the budget by paying VAT through the state digital platform.

There are also other prospects for applying blockchain technology to ensure transition to the model of relations between tax authorities and taxpayers. With regard 
to such prospects, it is essential to indicate both their benefits and possible risks that might arise in fulfilling tax obligations based on blockchain technology.

1. Creation of the system of transactional (automatic) taxation with "smart" taxes whose collection is carried out automatically at the time of the taxable transaction, that is, in "real time".

Such taxes can be oriented towards the use of distributed business ledgers in the online system. S.A. Filin and L.A. Chaikovskaya note that such introduction of blockchain technology into the process of calculating and paying (collecting) taxes is currently the area of tax authorities' activity that is discussed at the conceptual level due to existing technical and other problems; their solution is necessary for its successful implementation (Filin \& Tchaikovskaya, 2020: 940-958).

It must be assumed that the first step towards "smart taxes" introduction is creation of a taxation system in the form of a tax on professional income for the so-called self-employed taxpayers on the basis of the provisions of the Federal Law No. 422-FZ dated November 27, 2018 On the Experiment to Establish Special Tax Regime on Professional Income (hereinafter - Federal Law No. 422).

Mikhail Mishutin, being the head of the Federal Tax Service of Russia, announced formation of transactional virtual environment operated by tax authorities with launching My Tax mobile application; its creation is associated with administration of calculating and payment of the special tax regime called Professional Tax income. Describing the tax on professional income and emphasizing the importance of its legal structure in the process of digitalization of taxation sphere, Mikhail Mishustin noted that it creates a virtual transactional environment in the form of a closed digital ecosystem where all business entities will make transactions. As a result, the economy will become transparent by default and the Federal Tax Service of Russia will be able to automatically calculate and withhold taxes right at the time of transactions ${ }^{4}$.

According to the authors, transactional taxation in Russia is currently at the stage of formation, which follows from the analysis of the content of the provisions of Federal Law No. 422. Calculation and payment of tax on professional income is carried out on the basis of the "classical mechanism" which involves calculation of tax by the tax authority and sending notification to the taxpayer for payment.

2. To realize the possibility of paying tax "in real time", it is necessary to develop legal regulation that determines the status of the so-called (in accordance with Article 3 of the Federal Law No. 422) operators of electronic platforms who are playing the role of intermediaries in relations between tax authorities, taxpayers and banks (Lyutova, 2020:56-67). Only then functioning of such operators/technological intermediaries based on the blockchain technology will be possible. In this case, calculation and payment of professional income tax will be carried out automatically upon receipt of payment for services provided to

\footnotetext{
${ }^{4}$ Digital transformation of tax authorities became the main topic of the XII plenary session of the OECD Forum on Tax Administration. Available at: https://www.nalog.ru/rn77/news/activities_fts/8587982/ / [Accessed of February 5, 2021].
} 
self-employed persons. It is assumed that the function of "automatic tax deduction" should appear as the additional option for each of the operators of electronic platforms. Therefore, tax authorities will not take part in the process of calculating the professional income tax since it will be automatically transferred to the accounts of the Federal Treasury. Further on, information on taxable transactions will come to the tax authorities directly from operators of electronic platforms which implies the exemption of the taxpayer from obligation to create a check and transfer it through My Tax application.

The risks that may arise from blockchain technology introduction into transactional taxation consist in potential possibility of abandoning tax control as a type of activity in the future. R.M. Yankovsky analyzing the process of employing blockchain notes: "In blockchain technology... there is a threat to government regulation since technology implies effective self-regulation on the basis of consensus without involving legal mechanisms. In the future, this will lead to the loss of a part of the functions of the settlement sphere by the state which, naturally, does not correspond to its interests" (Yankovsky, 2018:45-51). In our opinion, transactional taxation transforms tax administration; as a result, tax control will be minimized through the active use of the tax monitoring method.

It must be assumed that the use of operators of electronic platforms as technological intermediaries in tax relations does not imply that they will replace tax authorities and claim to perform the functions / exercise the powers of a public authority, at least in the short term. Such a model of relationship is aimed, in our opinion, solely at stimulating taxpayers to "get out of the shadows" and redistribute functions among private subjects of tax legal relations. It seems that further informatization in one way or another will lead to the transfer of a number of actions performed by counterparties and having tax consequences into a digital format. The sphere of taxation will be no exception.

In this regard, tax control can also relate to taxpayers' tax registration, as well as tax audits. We consider it logical to establish the tax authority for random inspections of operators of electronic platforms with regulatory restrictions on their timing and number, which in the near future will be mainly carried out in the form of tax monitoring in accordance with the provisions of the Government Order of the Russian Federation No. 381-r of February 21, 2020 On approval of the Concept for the Development and Functioning of tax monitoring system in the Russian Federation. The issues of legal regulation of tax authorities' powers applying a risk-based approach in implementing tax monitoring are one of the most controversial when discussing digitalization of tax control (Kucheryavenko, 2017:45 - 63; Khavanova, 2017:81—91; Khvan, 2017:161-189).

3. Application of blockchain technology in the implementation of goods traceability.

The regulatory framework for the formation of a traceability system was laid by the Agreement on the mechanism of traceability of goods imported into the customs territory of the Eurasian Economic Union, concluded in Nur-Sultan 
on May 29, 2019. In pursuance of the international agreements reached on the territory of the Russian Federation, initially by the Decree of the Government of the Russian Federation No. 807 dated June 25, 2019 On Conducting an Experiment on the Traceability of Goods Released in the Russian Federation, it was established that a corresponding experiment was carried out from July 1 to December 31, 2020.

On the basis of Federal Law No. 371-FZ dated 09.11.2020, Article 23 of the Tax Code of the Russian Federation was supplemented with clause 2.3, which comes into force on 01.07.2021. Under this clause, taxpayers carrying out transactions with goods subject to traceability in accordance with the legislation are required to provide reports on transactions with goods subject to traceability, and documents containing traceability details, in the cases and in the manner established by the Government of the Russian Federation.

R.M. Shishkin asserts (Shishkin, 2019:124) that the main characteristic of the system of traceability of goods (works, services) will be an electronic document flow, including for taxpayers applying special tax regimes, which, in his opinion, will significantly simplify interaction between the state and a conscientious taxpayer. Indeed, information transmission by a taxpayer in fulfilling a tax obligation arising from the product traceability system is carried out electronically; at the same time, the modern stage of traceability can be considered "documentary", since it does not imply full automation of the corresponding process and refusal from tax reporting.

Thus, an obvious drawback of the traceability system in its modern version is the increasing burden on the tax authorities and taxpayers associated with the emergence of a new reporting obligation for goods that fall under the traceability system. According to the just remark of A.N. Tregubov (Tregubov, 2019:16-18), the tax and customs authorities thus increase the burden associated with the comparative analysis of a large amount of data contained in accounting, shipping and customs documents.

It seems to us that the use of blockchain technology to analyze the data array associated with functioning of traceability system would be very effective. This conclusion is confirmed by foreign experience; for example, this practice is quite common in Kazakhstan.

According to information provided by E.S. Sinyagovskaya and N.B. Kuroptev, Virtual warehouse module is implemented in traceability system based on the Electronic invoices information system which allows to automatically calculate the balances of goods in the taxpayer's warehouse, as well as track the movement of goods chain (from import to final consumption,) in real time (Sinyagovskaya \& Kuroptev. 2020:33). As potential difficulties that may arise on the way of implementing new technologies in the product traceability system, the authors mention the initial need to create product classifiers in the form of unified digital registers, access to which will be the same as for government agencies and private entities. The most controversial issue in this project is the volume of information contained in such registers. 
When introducing blockchain technology into legal regulation of relations concerning traceability of goods, based on such foreign experience, it is necessary to be guided by the following principles: security, protection of personal data, decentralization, transparency, accessibility, and consensus (trust).

Safety. Each participant engaged in the system is obliged to ensure security by encrypting the data. Those who commit unreasonable actions are responsible for a frivolous attitude towards safety.

Hacker attacks, fraud, identity theft, spam, malware, viruses - all these threaten human security. The average user has to rely on the protection of his/her information with simple passwords.

In the digital age, technological security is a prerequisite for human security in society. With the vulnerability of digital identity protection, a fraudster from the other end of the world can commit illegal actions; as a result, a person can lose all of his/her money. The blockchain has a robust design and transparency thanks to which people can safely exchange values and control everything that happens with their data (Tapscott, 2018:70).

In Russia, this principle is implemented in the comprehensive protection of consumer rights to receive financial services. For example, the Bank of Russia plans to adopt basic standards to protect the rights and legitimate interests of consumers of financial services, consisting of control measures, increasing financial literacy of population, and communicating information on variability of financial products provided (Tsindeliani, 2019:42).

Protection of personal data. Individuals control their own data. A person decides what, when and how much to say about their personality. Privacy is a fundamental human right and the foundation of a democratic society. Over the years of Internet existence, public and private organizations have accumulated in their databases a large amount of confidential information about citizens and organizations, including without their knowledge.

There is no personal identification in the blockchain. You do not need to provide personal information (name, email address, phone number) to use the Bitcoin software. The network itself does not require identification. In a simplified way, the action is as follows: side A transfers bitcoins from its address to side B. Personal data does not appear. The network confirms that certain number of bitcoins was controlled by side A, who then authorized the transaction. Afterwards the network records that these bitcoins are now controlled by side B. For comparison, you can imagine the credit card system. At the center of such a relationship is personal data. And it is possible that a huge number of addresses and phone numbers can become the prey of intruders if the security system is violated. In the blockchain, the participants, can remain anonymous if they wish (Tapscott, 2018:71-72). The network allows to select a specific level of anonymity for each transaction. Thus, the personal data of each participant is more reliably protected in the blockchain. The subject of the cryptocurrency market cannot access the personal data of another user. The only thing that can be found out is the pseudonym (nickname) of the other party. 
Decentralization. Cryptocurrency transaction data and cryptocurrency wallet data are stored on a distributed system consisting of many separate computers. This distributed system does not have a single control center. Neither side is capable of crashing the system. If a powerful actor needs to disconnect or isolate one or more participants, the system will continue to work as no one can control the entire network.

Organizations with a larger user base, such as banks, can, at the request of the state, collect, analyze and release information without the consent of the people, i.e. to act contrary to their opinion. In the blockchain, the costs of trying to control bitcoins significantly exceed the potential financial benefits, namely, huge computing power and, therefore, electricity will have to be consumed. Bitcoins do not exist on their own; they are not documents or files, they only represent constantly changing income and expenses. Therefore, they cannot be copied or lost. Bitcoin ownership rights are recorded in the main journal and identified as belonging to a specific owner. The owner may lose the ability to manage the account, for example, by losing the password to the electronic wallet, but it is literally impossible to lose cryptocurrency (Vigna, 2018:166).

Availability. The physical availability of a blockchain must be weighed against affordability and ease of use. In accordance with the Strategy for Increasing Financial Inclusion in the Russian Federation, approved by the Bank of Russia, consumer protection in the financial sector and increasing financial literacy is a priority $^{5}$. In this sense, it is planned to improve the regulatory framework. Also, the concept of financial affordability has been defined; it is the state in the financial market where participants in financial relations (small and medium-sized businesses, citizens) have an affordable opportunity to receive the required amount of financial services ${ }^{6}$.

In this regard, one can note a significant growth in automated financial services, an increase in the level of self-service in the banking sector.

Consequently, the principle of accessibility is characterized not only by the physical simplicity of the provision of financial services, but also by their quality, safety, economy, uninterrupted operation, variability, continuity and extraterritoriality (Tsindeliani, 2019:40).

Transparency. Any participant in the cryptocurrency market has access to all information on transactions that are stored using blockchain technology. At the same time, the data cannot be changed by participants or other subjects, it cannot be manipulated; such state of things considerably reduces the possibility of financial fraud.

Personal rights and freedoms are transparent, universally recognized, respected and legally protected. In the early days of the digital economy, people sought to find ways to exercise these rights. Internet became a new medium for news, entertainment,

\footnotetext{
${ }^{5}$ Official website of the Bank of Russia. Available at: https://www.cbr.ru/Content/Document/File/44104/ str_30032018.pdf / [Accessed February 5, 2021].

6 Официальный сайт Банка России. Режим доступа: https://www.cbr.ru/finmarket/development/ development_affor/ (дата обращения: 05.02.2021).
} 
copyright establishment and protection, sale and purchase, etc. Thus, people had to rely on intermediaries to manage transactions, who could refuse, delay, conduct or cancel the deal.

In combination with crypto-protection, the blockchain does not allow doublespending and registers the ownership of each unit of the digital currency in circulation. Any transaction cannot be changed or canceled. In the blockchain, it is impossible to sell what does not belong to the participant (both material and intellectual property).

Consensus (trust). Trust is an internal element of the entire process. Compliance with ethical standards is coded and distributed among all participants and is not monitored by anyone. The interaction of subjects proceeds from the fact that everyone acts honestly, responsibly, transparently, taking into account other people's interests. Elements of ethics are encoded in decision-making rights and in the operations themselves. Violation of ethics requires a lot of money, time, reputation, or is ruled out altogether.

Before the digital age, it was impossible to conduct business directly on the Internet, since money is inherently different from other material or intellectual values; it cannot exist in two places at the same time. A mechanism has been created in the blockchain that deals with the problem of double spending in the same way as a reliable third party. The network records the time of the first transaction and prevents respending of this bitcoin. Transactions in the blockchain are open and cannot be hidden. Hence, this platform provides trust in transactions and other recorded information, regardless of the actions of the other party. Trust is a prerequisite for the digital economy, and blockchain opens up many opportunities for a new type of reliable, credible and massive collaboration (Tapscott, 2018:56-60).

4. Application of blockchain technology to minimize tax reporting, as well as to exempt from the obligation to submit it for certain categories of taxpayers.

According to the authors, the issues of legal regulation of the tax obligation to provide tax reporting in the context of the blockchain technology deserve an independent scientific study; this article is only outlining separate "benchmarks" that characterize the main problems and directions of development of tax legislation in this area.

First of all, it should be noted that despite being mentioned in a number of policy documents, the need to take measures to minimize tax reporting through the use of information technology, which became available in the context of developing digital services, in practice this approach has the opposite trend. In fact, the Address of the President of the Russian Federation to the Federal Assembly of 03/01/2018 points out the value of "drastic simplification" of tax reporting for entrepreneurs using cash registers, and for individual entrepreneurs and the self-employed using digital services; according to Russian President it is necessary to exempt these categories of entrepreneurs from reporting and turn the tax payment into a simple transaction. Also, simplification of tax reporting as a goal of national development was indicated in the National Project "Small and Medium Enterprises and Support 
for Individual Entrepreneurial Initiatives", adopted in pursuance of the Presidential Decree of the Russian Federation No. 204 of May 7, 2018 On National Goals and Strategic Development Objectives of the Russian Federation for the Period up to 2024.

An example of a simplified procedure for submitting tax reports is, for example, reporting on the property tax of organizations (this procedure came into force in 2020): a taxpayer registered with several tax authorities of the constituent entities of the Russian Federation at the location of the real estate objects belonging to him, whose tax base is determined as their average annual value, has the right to submit a tax return in respect of all such objects to one of the specified tax authorities of their choice. For this, in accordance with paragraph 1 of Art. 386 of the Tax Code of the Russian Federation, he/she must annually notify the Federal Tax Service Administration for the constituent entity of the Russian Federation about the choice of the tax authority in the prescribed form. Despite the fact that property tax is regional, the tax legislation does not provide for the powers related to regulating tax reporting issues for the constituent entities of the Russian Federation; the rights and obligations of tax authorities in relation to tax returns are regulated by the Tax Code of the Russian Federation uniformly, without taking into account regional specifics.

For the purposes of simplifying tax reporting, it would be advisable to provide for the obligation to submit only one declaration without the need for notification and establish the right of the regional FTS of Russia to automatically exchange information about submitted reports in cases where this is provided for by the law of a constituent entity of the Russian Federation, as well as establish the procedure for such an exchange. In our opinion, imposing obligation on a taxpayer to provide notification of tax return submission does not facilitate the procedure. At the same time, such a procedure does not make sense because the tax authorities have the relevant information in the information resource; it is regulated by tax authorities, but the rules are not available for the taxpayer to study. Establishing the possibility of information exchange between tax authorities of the constituent entities at the level of regional laws, but not at the level of the documents for official use, will become an effective tool to protect taxpayer' interests in potentially possible cases of their rights' violation.

As a universal option for minimizing tax reporting and subsequent general exemption from the corresponding tax obligation is accessing by tax authorities the primary documents of taxpayers "in real time", which can be ensured with the help of blockchain technology.

In this regard, tax monitoring as well as the use of online cash registers may be looked at as "preparatory measures", provided that blockchain is introduced into tax administration.

Another option for using blockchain technology for the prospective refusal of tax reporting may be inclusion of tax authorities into the smart contract mechanism used in relation to taxable transactions; as a result, tax can be calculated in an automatic 
transactional manner, and the need for tax reporting is levelled by the properties of the distributed ledger as the basis for blockchain operation. Such properties imply the ability to track taxable actions of taxpayers at the time of their commission without the possibility of any retroactive changes. It seems that such approach can be introduced and tested by the state in the near future, provided that the tax authorities obtain access to the primary documentation of taxpayers.

In addition to the obvious benefits of using blockchain technology to optimize tax reporting, there are a number of possible negative aspects that should also be taken into account when developing legal regulation of blockchain implementation in tax administration. For example, I.A. Khavanova points to certain difficulties in taxation of transactions that may arise when using smart contracts: for example, problems associated with transfer pricing arising from profits gained through changes in the value of cryptocurrencies in case of connecting smart contracts to various decentralized exchanges for automatic transactions with cryptocurrencies and tokens; issues of documentary confirmation of transactions, proof of justification of expenses, justification of tax benefits and business purpose (Khavanova, 2020:38).

In addition, it can be noted that when using smart contracts in tax administration, other questions may arise: who will create and administer a smart contract, will it be private or public, and how, when choosing one or another option, is their security ensured and transparency guaranteed? Other relative questions are: where is surplus value created and how should it be taxed?

Another risk of using blockchain technology to waive the obligation of tax reporting is conventionally designated by researchers "subjective factor". As Gra-cheva argues "not all taxable persons have the opportunity, the necessary competencies and the desire to use modern digital methods" (Gracheva (ed.), 2020:118).

\section{Conclusion}

Thus, the review of academic literature on the development of tax and legal regulation on applying blockchain technology, carried out within the framework of this scientific article, allows us to draw the main conclusion about the undoubted value of legal regulation of tax relations that arise, change and terminate due to the transition of taxation to a new stage of digital development - digital maturity.

It seems that the main drawback of the current state of legal regulation of tax relations associated with blockchain technology is the lack of a unified terminological and methodological approach to the formation of tax legislation development process. The result of this is legal uncertainty in the following issues: lack of the mechanism for legal regulation of tax consequences of relations associated with digital financial assets that is adequate to modern realities; incompleteness of transition process to transactional taxation, experimentally established for self-employed taxpayers; introduction of product traceability system, which implies additional "documentary" tax obligations. 


\section{References / Список литературы}

Abramov, V., Popov, N., Istomin, E., Sokolov, A., Popova, A. \& Levina, A. (2020) Blockchain and big data technologies within geo-information support for arctic projects. Proceedings of the 33rd International Business Information Management Association Conference, IBIMA 2019: Education Excellence and Innovation Management through Vision. Granada, Spain. Doi: 10.1088/1757-899X/940/1/012003

Barakina, E.Y. (2018) The concept of "blockchain technology" and its application in the national payment system of the Russian Federation: issues of legal regulation. Banking law. (1), 53-58 (in Russian).

Баракина Е.Ю. Понятие «технология блокчейн» и его применение в национальной платежной системе Российской Федерации: вопросы правового регулирования // Банковское право. 2018. № 1. С. 53-58.

Demin, A.V. (2017) Dispositivity and taxation: commentary on tax administration legislation and practices. ConsultantPlus. (in Russian).

Демин A.B. Диспозитивность и налогообложение: комментарий законодательства и практики налогового администрирования // СПС КонсультантПлюс, 2017.

Filin, S.A. \& Tchaikovskaya, L.A. (2020) Taxes in the digital economy and cyberphysical technologies. International accounting. (8), 940-958. (in Russian).

Филин С.А., Чайковская Л.А. Налоги в цифровой экономике и киберфизические технологии // Международный бухгалтерский учет. 2020. № 8. С. 940-958.

Gracheva, E.Yu. (ed.) (2020) Current problems of financial law in the conditions of digitalization of the economy: monograph. Moscow, Prospect Publ. (in Russian).

Актуальные проблемы финансового права в условиях цифровизации экономики: монография / под ред. Е.Ю. Грачевой. М.: Проспект, 2020. 256 с.

Hwan, L.B. (2017) Administrative discretion in tax legal relations (based on the materials of the Republic of Uzbekistan). Public Law Yearbook 2017: Discretion and Evaluation Concepts in Administrative Law, pp. 161-189 (in Russian).

Хван Л.Б. Административное усмотрение в налоговых правоотношениях (по материалам Республики Узбекистан) // Ежегодник публичного права 2017: Усмотрение и оценочные понятия в административном праве. 2017. С. 161-189.

Khavanova, I.A. (2017) Tax jurisdiction: possible and deferred risks. Journal of Russian Law. (12), $81-91$ (in Russian).

Хаванова И.А. Налоговая юрисдикция: грани возможного и отсроченные риски // Журнал российского права. 2017. № 12. С. $81-91$.

Khavanova, I.A. (2020) Smart contracts: the phenomenon of techno-legal regulation and taxes. Financial law. (3), 36-38 (in Russian).

Хаванова И.А. Смарт-контракты: феномен техноправового регулирования и налоги // Финансовое право. 2020. № 3. С. 36-38.

Kucheryavenko, N.P. (2017) Features of discretion in tax and legal regulation. In: Public Law Yearbook 2017: Discretion and evaluation concepts in administrative law. Moscow, Infotropik Media Publ. pp. 45-63. (in Russian).

Кучерявенко Н.П. Особенности усмотрения в налогово-правовом регулировании // Ежегодник публичного права 2017: Усмотрение и оценочные понятия в административном праве. М.: Инфотропик Медиа, 2017. С. 45-63.

Lyutova, O.I. (2020) Operators of electronic platforms as participants in tax relations of the digital era (using the example of tax on professional income). Pravoprimenenie. (4), 56-67. (in Russian). 
Лютова О.И. Операторы электронных площадок как участники налоговых отношений цифровой эпохи (на примере налога на профессиональный доход) // Правоприменение. 2020. T. 4. № 4. C. 56-67.

Mamonova, I.V. (2018) Trends and prospects of tax administration in modern conditions. Taxes. (1), 37-41. (in Russian).

Мамонова И.В. Тенденции и перспективы налогового администрирования в современных условиях // Налоги. 2018. № 1. С. 37-41.

Migacheva, E.V. (2018) Tax control in the context of the development of the digital economy. Financial law. (8), 21-25 (in Russian).

Мигачева E.B. Налоговый контроль в условиях развития цифровой экономики // Финансовое право. 2018. № 8. С. 21-25.

Nam, K.V. (2019) Legal problems related to the use of blockchain. Judge. (2), 24-27 (in Russian). Нам К.B. Правовые проблемы, связанные с применением блокчейна // Судья. 2019. № 2. C. $24-27$.

Rozhkova, M.A. (2018) Internet law: a collection of papers. Moscow, Statute Publ. (in Russian). Рожкова М.А. Право в сфере Интернета: сборник статей / отв. ред. М.А. Рожкова. М.: Статут, $2018.528 \mathrm{c}$.

Shishkin, R.M. (2019) Tax benefit in business fragmentation: the position of tax authorities and courts. Moscow, Editorial Board of Rossiyskaya Gazeta Publ. Issue 3. (in Russian).

Шишкин P.M. Налоговая выгода при дроблении бизнеса: позиция налоговых органов и судебных инстанций. М.: Редакция «Российской газеты». Вып. 3. 2019. 176 с.

Sinyagovskaya, E.S. \& Kuroptev, N.B. (2020) Problems of introduction of traceability system of goods in EAEU. Innovation Technology Newsletter. 3 (915), 33-38 (in Russian).

Синяговская E.C., Куроптев Н.Б. Проблемы внедрения системы прослеживаемости товаров в ЕАЭС // Бюллетень инновационных технологий. 2020. Т. 4. № 3 (915). С. 33-38.

Swan, M. (2015) Blockchain: Blueprint for a New Economy. Boston, O’Reilly Media.

Tabernakulov, A. \& Kuifmann, Y. (2019) Blockchain in practice. Moscow, Alpina Pablisher. (in Russian).

Табернакулов А., Койфманн Я. Блокчейн на практике. М.: Альпина Паблишер, 2019. 264 с.

Talapina, E.V. (2019) Blockchain in public administration: legal prospects and risks. Laws of Russia: experience, analysis, practice. (5), 77-82 (in Russian).

Талапина Э.В. Блокчейн в государственном управлении: правовые перспективы и риски // Законы России: опыт, анализ, практика. 2019. № 5. С. 77-82.

Tapscott, D. \& Tapscott, A. (2016) Blockchain Revolution: How the Technology Behind Bitcoin is Changing Money, Business, and the World. London, Portfolio.

Tapskott, D. (2018) Blockchain technology: what drives the financial revolution today. Moscow, Eksmo Publ. (in Russian).

Tancкотт Д. Технология блокчейн: то, что движет финансовой революцией сегодня. М.: Эксмо, 2018. 448 с.

Tikhonova, A.V. (2020) Cryptocurrency and blockchain: scope of application in Russian tax law. Taxes and taxation. (4), $1-9$ (in Russian).

Тихонова A.B. Криптовалюта и блокчейн: сфера применения в налоговом праве России // Налоги и налогообложение. 2020. № 4. С. 1-9.

Tregubov, A.N. (2019) Establishment of a traceability system as a response to smuggling of goods. Customs affairs. (3), 16-18 (in Russian).

Трегубов А.Н. Создание системы прослеживаемости как меры противодействия незаконному ввозу товаров // Таможенное дело. 2019. № 3. С. 16-18.

Tsindeliani, I.A. (ed.). (2019) Financial law in the development of the digital economy: monograph. Moscow, Prospect Publ. (in Russian). 
Финансовое право в условиях развития цифровой экономики: монография / под ред. И.А. Цинделиани. М.: Проспект, 2019. 320 с.

Varnavsky, A.V., Buryakova, A.O. \& Sebechenko, E.V. (2020) Blockchain in the service of the state: monograph. Moscow, KNORUS Publ. (in Russian).

Варнавский А.В., Бурякова А.О., Себеченко Е.В. Блокчейн на службе государства: монография. М.: КНОРУС, 2020. С. 35-46.

Viña, P. (2018) The era of cryptocurrencies. How Bitcoin and blockchain are changing the world economic order. Moscow: Mann, Ivanov and Ferber Publ. (in Russian).

Винья П. Эпоха криптовалют. Как биткоин и блокчейн меняют мировой экономический порядок. М.: Манн, Иванов и Фербер, 2018. 575 с.

Xu, Y. \& Huang, Y. (2020) Segment blockchain: a size reduced storage mechanism for blockchain. International Journal of Energy Sector Management. (8), 17434-17441.

Yankovsky, R.M. (2018) Problems of legal regulation of cryptocurrencies. Business law. Business and Law application. (1), 45-51. (in Russian).

Янковский Р.М. Проблемы правового регулирования криптовалют // Предпринимательское право. Приложение «Бизнес и право». 2018. № 1. С. 45-51.

Zhuravlev, A., Brisov, Yu., Yankovsky, R. \& Levashenko, A. (2020) The evolution of cryptoeconomics and recent trends in decentralized finance. Bank Review. (10), 32-35. (in Russian).

Журавлев А., Брисов Ю., Янковский Р., Левашенко А. Эволюция криптоэкономики и последние тренды децентрализованных финансов // Банковское обозрение. 2020. № 10. С. $32-35$.

\section{About the authors:}

Olga I. Lyutova - Candidate of Legal Sciences, leading researcher at the Institute of State and Municipal Administration, National Research University Higher School of Economics (NRU HSE); 20 Myasnitskaya str., Moscow, 101000, Russian Federation

\section{ORCID ID: 0000-0002-6603-8859}

e-mail: olyutova@hse.ru

Irina D. Fialkovskaya - Candidate of Legal Sciences, Associate Professor of the Department of Administrative and Financial Law, National Research Nizhny Novgorod State University named after N.I. Lobachevsky; 23 Gagarina pr., Nizhny Novgorod, 603022, Russian Federation

$$
\text { e-mail:i.fialk@yandex.ru }
$$

\section{Об авторах:}

Лютова Ольга Игоревна - кандидат юридических наук, ведущий научный сотрудник, Институт государственного и муниципального управления; Национальный исследовательский университет «Высшая школа экономики»; Российская Федерация, 101000, г. Москва, ул. Мясницкая, д. 11

\section{ORCID ID: 0000-0002-6603-8859}

e-mail: olyutova@hse.ru

Фиалковская Ирина Дмитриевна - кандидат юридических наук, доцент, доцент кафедры административного и финансового права, Национальный исследовательский Нижегородский государственный университет им. Н.И. Лобачевского; Российская Федерация, 603022, г. Нижний Новгород, пр. Гагарина, д. 23

e-mail: i.fialk@yandex.ru 